\title{
Pengaruh Penambahan Bahan Organik dalam Pembuatan Pupuk Organik Padat Sludge Biogas Feses Sapi Perah terhadap Kandungan N, P dan K
}

\author{
The Effect of Addition of Some Organic Material in the Manufacture of \\ Solid Organic Fertilizer of Biogas Sludge from Dairy Faeces on N, P and K Content
}

\section{E. Vebriyanti, E. Purwati, dan Apriman}

Fakultas Peternakan Universitas Andalas

Kampus Unand Limau Manis Padang, 25163

e-mail: vebriyantiely@yahoo.co.id

(Diterima: 12 Juni 2011; Disetujui: 18 September 2011)

\begin{abstract}
This research aims to test the hypothesis that a combination of solid Sludge biogas from manure of dairy cows with a different ratio of water and the addition of quality-enhancing organic material can increase the content of $N, P$ and $K$. This research method using a randomized block design (RBD) with 3 $x 4$ factorial design with two replicates. Factor $A$ is the solid Sludge and dairy manure biogas, Factor $B$ is the quality-enhancing organic material (blood meal, bone meal, rice husk ash and mixed). Variables observed included $\mathrm{N}$-organic content, $\mathrm{PO}_{4}$ and $\mathrm{K}_{2} \mathrm{O}$. The results showed solid Sludge composting dairy manure biogas with different ratio of water and adding blood meal increased the organic content of the $\mathrm{N}-1.6135 \%$, faecal Sludge dairy cows with a different ratio of water and the addition of bone meal to improve the content of $2.9089 \% \mathrm{PO}_{4}$ dairy manure and Sludge with different ratio of water and the addition of a mixture of organic materials (1\% blood meal, bone meal ash 3\% and 3\%) increase the content of $0.4382 \% \mathrm{~K}_{2} \mathrm{O}$.
\end{abstract}

Keywords: biogas, cattle feses, organic N, $P, K$

\section{PENDAHULUAN}

Limbah yang dihasilkan selama proses pemeliharaan ternak oleh peternak menjadi salah satu sumber pencemaran lingkungan yang terdapat disekitar lokasi peternakan. Untuk mencegah terjadinya pencermaran lingkungan yang lebih lanjut oleh limbah selama pemeliharaan ternak diperlukan suatu teknologi yang tepat guna dan bisa diaplikasikan sendiri oleh masyarakat. Biogas merupakan campuran dari beberapa gas, tergolong bahan bakar yang merupakan hasil fermentasi dari bahan organik dalam kondisi anaerob dan gas yang dominan adalah gas metan $\left(\mathrm{CH}_{4}\right)$ dan gas karbondioksida $\left(\mathrm{CO}_{2}\right)$. Dengan pemanfaatan biogas ini dalam menangani masalah limbah yang dihasilkan oleh usaha peternakan, terutama limbah yang berupa feses dan urin ternak ruminansia maka tidak akan terjadi pencemaran lingkungan terutama disekitar lokasi usaha peternakan yang disebabkan oleh kegiatan pemeliharaan ternak. Selain menghasilkan gas dan juga mengurangi pencemaran lingkungan yang terjadi, lumpur (Sludge) atau sisa hasil proses biogas yang berupa padatan dan cairan bisa digunakan sebagai pupuk organik untuk tanaman. Sludge merupakan limbah yang dapat dijadikan pupuk organik walaupun Sludge adalah bahan keluaran dari sisa proses pembuatan biogas berupa lumpur dan bisa langsung digunakan untuk memupuk tanaman. Sludge dapat dipisahkan menjadi pupuk organik padat dan pupuk organik cair. Kandungan unsur hara dalam pupuk organik tidak terlalu tinggi, tetapi pupuk organik memiliki keistimewaan lain yaitu dapat memperbaiki sifat fisik tanah, seperti: permeabilitas, porositas tanah, struktur tanah, daya menahan air, dan kapasitas tukar kation tanah.

Unsur hara yang penting bagi tanaman seperti nitrogen $(\mathrm{N})$, fosfor $(\mathrm{P})$ dan kalium (K). N, P dan $\mathrm{K}$ ini tergolong unsur hara 
essensial dan unsur hara makro yaitu unsur hara yang penting bagi tanaman dan dibutuhkan dalam jumlah yang banyak. Dalam pembuatan pupuk organik, terjadi proses fermentasi atau dekomposisi yang dilakukan oleh mikroorganisme pengurai. Mikroorganisme akan menghancurkan sisasisa bahan organik dan unsur-unsur yang sudah terurai diikat menjadi senyawa. Penelitian ini bertujuan untuk mengetahui pengaruh interaksi Sludge biogas feses sapi perah dengan penambahan bahan organik yang berbeda terhadap kandungan nitrogen, fosfor dan kalium pupuk organik padat yang dihasilkan.

\section{METODE}

Penelitian ini menggunakan bahan baku yang berasal dari Sludge padat dari 9 digester biogas terdiri dari feses sapi perah dengan jumlah $36 \mathrm{~kg}$ dan perbandingan air yang berbeda, yang diperoleh dari UPT Fakultas Peternakan Universitas Andalas. Setelah dilakukan pemisahan antara padatan dan cairan limbah hasil biogas, maka diperoleh jumlah padatan sebanyak $27 \mathrm{~kg}$ untuk diolah sebagai pupuk padat organik dan beberapa jenis bahan yang digunakan untuk meningkatkan kandungan unsur hara pada pupuk organik yang dihasilkan, yakni tepung darah sebanyak $90 \mathrm{~g}$, tepung tulang $270 \mathrm{~g}$ dan abu sekam $270 \mathrm{~g}$.

Bahan-bahan yang digunakan untuk analisis laboratorium adalah $\mathrm{H}_{2} \mathrm{SO}_{4}$ pekat, $\mathrm{H}_{2} \mathrm{SO}_{4}, \mathrm{H}_{3} \mathrm{BO}_{3}$, larutan $\mathrm{NaOH}$ dan dietil eter. Peralatan yang digunakan antara lain yaitu timbangan analitik, corong, labu kjehdal, labu distilasi, labu ukur $500 \mathrm{ml}$, erlenmeyer, pipet gondok, tabung reaksi, drum, ember, timbangan, saringan, pengaduk, kaus tangan karet dan plastik.

Penelitian ini terdiri atas dua faktor perlakuan yaitu: faktor A (Sludge padat biogas feses sapi dengan perbandingan air yang berbeda) dan faktor B (bahan organik: tepung darah, tepung tulang, abu sekam dan campuran) yang disusun dengan pola faktorial 3 x 4 dengan 2 ulangan dalam Rancangan Acak Kelompok.

Faktor A merupakan Sludge padat biogas yang terdiri dari :

$\mathrm{A}_{1}=$ Sludge padat biogas feses sapi perah + air $(1: 1)$

$\mathrm{A}_{2}=$ Sludge padat biogas feses sapi perah + air $(1: 2)$

$\mathrm{A}_{3}=$ Sludge padat biogas feses sapi perah + air $(1: 3)$

Faktor B merupakan jenis bahan organik :

$\mathrm{B}_{1}=$ tepung darah $(1 \%)$

$\mathrm{B}_{2}=$ tepung tulang $(3 \%)$

$\mathrm{B}_{3}=$ abu sekam (3\%)

$\mathrm{B}_{4}=$ campuran tepung darah, tepung tulang dan abu sekam

Model linier yang digunakan menurut Steel dan Torrie (1991) adalah sebagai berikut:

$\boldsymbol{Y}_{i j}=\boldsymbol{u}+\boldsymbol{A}_{i}+\boldsymbol{B}_{j}+\boldsymbol{A B}_{i j}+\boldsymbol{K}_{k}+\sum_{i j k}$ analisis dilanjutkan dengan uji DMRT (Duncans Multiple Range Test).

Peubah yang diamati

a. N-Organik.

b. Fosfor $\left(\mathrm{PO}_{4}\right)$

c. $\operatorname{Kalium}\left(\mathrm{K}_{2} \mathrm{O}\right)$

\section{Pelaksanaan penelitian}

1. Skema Pembuatan Biogas setelah dimodifikasi (Simamora, Salundik dan Wahyuni, 2006)

a). Persiapan instalasi pembuatan biogas.

b). Feses sapi perah ditimbang sebanyak 4 $\mathrm{kg}$.

c). Campuran diencerkan dengan air dengan perbandingan $1: 1,1: 2,1: 3$ dan diaduk rata.

d). Adonan (langkah poin c) dimasukkan dalam digester melalui pipa pemasukan.

e). Ditunggu setelah hari ke- 24, buka kran gas dan coba dinyalakan.

f). Biogas yang dihasilkan dapat digunakan untuk penerangan atau memasak. 


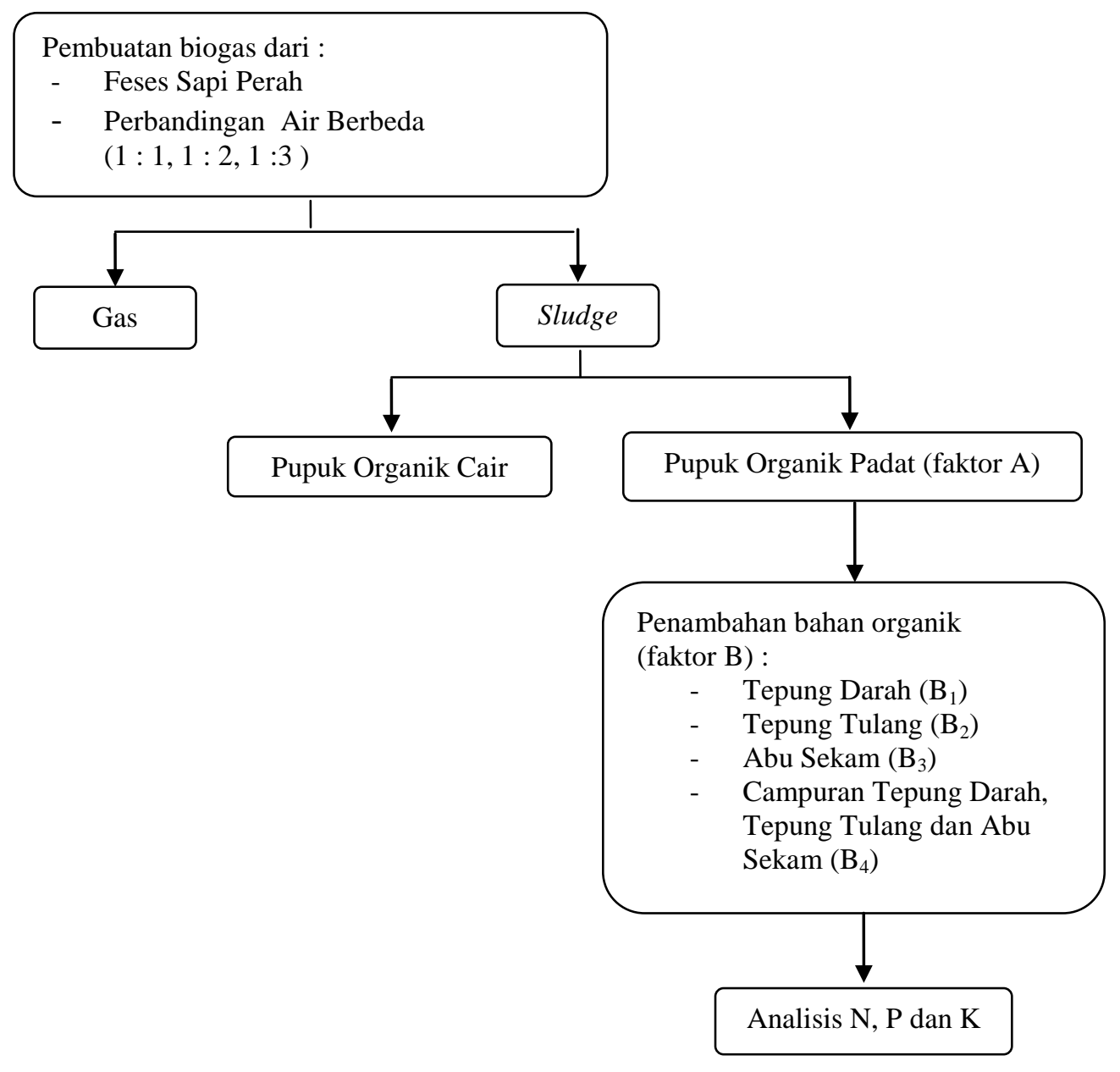

Gambar 1. Diagram Alir Pelaksanaan Penelitian

g). Lumpur yang keluar dari instalasi biogas (hari ke 25) dapat digunakan sebagai pupuk organik.

2. Skema Pembuatan Pupuk Organik Padat dari Sisa Pembuatan Biogas (Simamora dkk., 2006)

a). Persiapkan alat dan bahan

b). Pemisahan padatan dan cairan Sludge biogas, yang terdiri dari bahan baku feses sapi perah dengan konsentrasi air yang berbeda. Pemisahan dilakukan dengan penyaringan.

c). Setelah pemisahan diperoleh padatan sebanyak $3.000 \mathrm{~g}$ dari masing-masing digester, kemudian dibagi menjadi empat bagian untuk ditambahkan bahanbahan peningkatan (tepung darah, tepung tulang, abu sekam dan campuran) d). Bahan baku tersebut ditempatkan di ember plastik dan terlindung dari sinar matahari langsung maupun hujan.

3. Skema Pembuatan Bahan Organik Peningkat Mutu Pupuk Padat

a). Pembuatan Tepung Darah

Pembuatan tepung darah (Simamora dkk., 2006), dilakukan sebagai berikut:

Darah segar yang diperoleh dari Rumah Potong Hewan (RPH) dan ditambah garam $1 \%$, kemudian dimasak diatas nyala api sedang pada temperatur $80^{\circ} \mathrm{C}-85^{\circ} \mathrm{C}$ selama 2 jam sambil diaduk-aduk, hingga berwarna kuning kecoklatan. Setelah berwarna coklat darah diangkat, darah yang telah masak dikeringkan dibawah sinar matahari selama 2 hari. Darah yang telah kering digiling dengan lumpang hingga menghasilkan tepung darah yang masih kasar. Tepung darah yang masih kasar dihaluskan lagi 
dengan menggunakan blender dan diayak dengan mess 180 hingga diperoleh tepung darah yang halus. Dalam bentuk skema dapat dilihat pada Gambar 2.

\section{b). Tepung Tulang}

Pembuatan tepung tulang (Simamora dkk., 2006), dilakukan sebagai berikut:

1). Dibakar tulang hewan yang terkumpul dengan api unggun hingga berwarna gelap dan teksturnya mudah hancur atau remah.
2). Ditumbuk tulang tadi dengan menggunakan lumpang hingga diperoleh tepung tulang kasar, lalu ayak hingga diperoleh tepung tulang halus. Tepung tulang siap digunakan.

3). Tepung tulang siap untuk digunakan

c). Abu Sekam

Abu sekam diperoleh dari hasil pembakaran sekam padi, ditambahkan untuk meningkatkan kandungan unsur $\mathrm{K}$ pada pupuk organik padat (Simmamora dan Salundik, 2006).

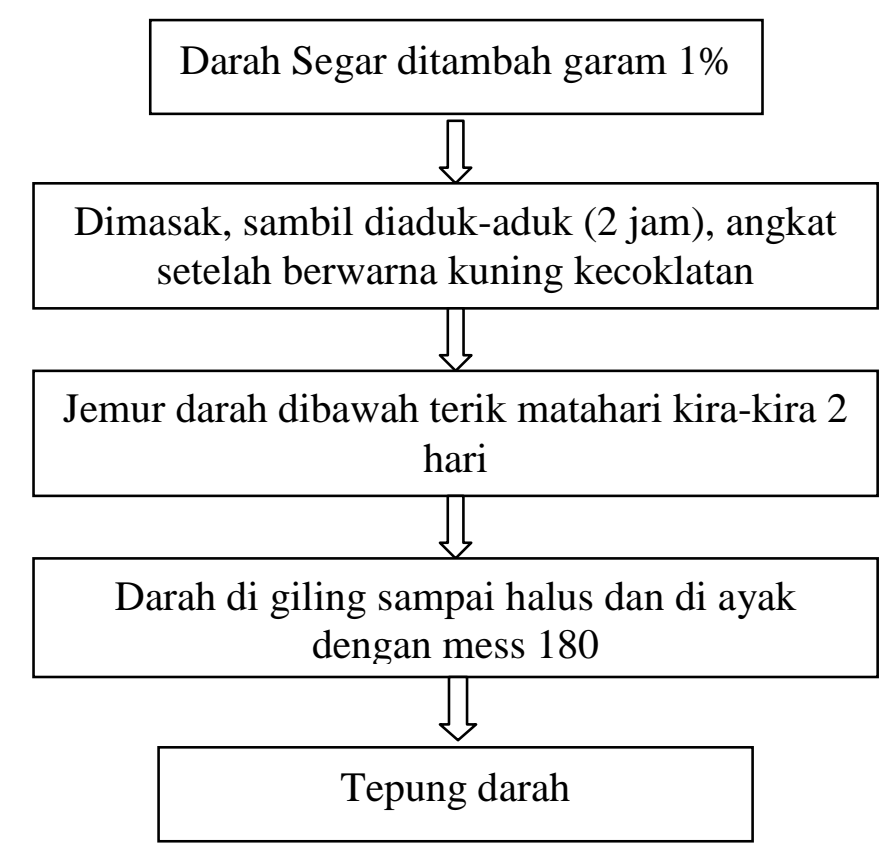

Gambar 2. Skema kerja pembuatan tepung darah

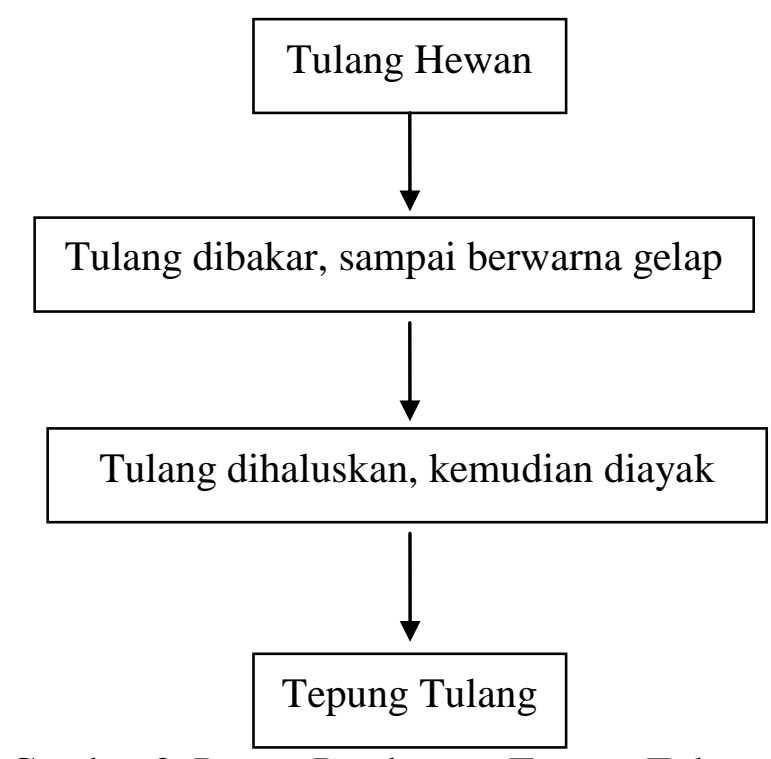

Gambar 3. Proses Pembuatan Tepung Tulang 
Penelitian ini dilakukan di Laboratorium Teknologi hasil ternak Fakultas Peternakan dan Laboratorium Ilmu Tanah Fakultas Pertanian Universitas Andalas.

\section{HASIL DAN PEMBAHASAN}

\section{Kandungan N-organik}

Hasil penelitian ini didapat kandungan $\mathrm{N}$-organik pupuk organik yang tertinggi terdapat pada perlakuan A2B1 yaitu sebesar $1,7790 \%$. Untuk lebih jelasnya kandungan $\mathrm{N}$-organik masing-masing perlakuan dapat dilihat pada Tabel 1 .

Interaksi antara faktor A dan Faktor B terhadap kandungan N-organik pupuk organik Sludge biogas memperlihatkan pengaruh yang berbeda nyata $(\mathrm{P}<0,05)$. Hasil uji lanjut Duncan's menunjukkan bahwa interaksi antara Sludge padat biogas dari feses sapi perah dengan perbandingan air yang berbeda dan penambahan beberapa bahan organik menunjukkan bahwa pada perbandingan antara Sludge dengan air 1:1 berbeda tidak nyata $(\mathrm{P}>0,05)$ kandungan $\mathrm{N}$ organik turun berbeda tidak nyata $(\mathrm{P}>0,05)$ dari Penambahan tepung darah (A1B1) ke penambahan tepung tulang (A1B2), penambahan abu sekam (A1B3) serta pada penambahan bahan organik campuran (A1B4), sedangkan pada perbandingan air 1:2 kandungan N-Organik antara A2B1 menunjukkan pengaruh berbeda nyata $(\mathrm{P}<0,05)$ dengan $(\mathrm{A} 2 \mathrm{~B} 3)$ dan $(\mathrm{A} 2 \mathrm{~B} 4)$ dan antara $\mathrm{A} 2 \mathrm{~B} 1$ berbeda tidak nyata $(\mathrm{P}>0,05)$ dengan A2B2. Berbeda tidak nyatanya hasil dari penelitian ini pada perlakuan A1B1 dengan A1B2 disebabkan karena terangkatnya nitrogen dalam bentuk amoniak ataupun gas nitrogen selama proses pengomposan serta pengemasan pupuk organik sebelum dilakukan analisis laboratorium. sesuai dengan pendapat Simamora dkk., (2006), menyatakan bahwa nitrogen mudah menguap dalam bentuk amoniak dan gas nitrogen selama proses dekomposisi berlangsung serta pada saat proses pengemasan pupuk organik itu sendiri.

Pada Sludge padat dengan perbandingan air 1:3 menunjukkan pengaruh yang berbeda tidak nyata $(\mathrm{P}>0,05)$ pada masingmasing perlakuan. Perbandingan air sangat mempengaruhi kualitas dari pupuk organik yang dihasilkan. Berbeda tidak nyatanya kandungan $\mathrm{N}$-organik yang dihasilkan pada perlakuan A3 (Sludge padat dengan perbandingan air 1:3) disebabkan terlalu encernya bahan baku di dalam digester sehingga proses fermentasi oleh mikroorganisme menjadi tidak sempurna. Sesuai dengan pendapat Solikhah (2006) yang menyatakan bahwa, media untuk proses fermentasi bahan baku biogas membutuhkan bahan kering 7\%-9\%, jika terlalu encer mikroba tidak dapat hidup semuanya dalam tangki pencerna. Suriawiria (2006) menambahkan, proses fermentasi akan berjalan dengan optimal jika kadar air yang terkandung dalam bahan yang digunakan harus dengan ratio yang tepat, ini dikarenakan air berperan sangat penting dalam proses biologis selama fermentasi bahan baku.

Tabel 1. Kandungan N-organik pupuk organik padat dari Sludge padat biogas feses sapi perah (\%)

\begin{tabular}{cccccc}
\hline \multirow{2}{*}{ Faktor A } & \multicolumn{4}{c}{ Faktor B } & \multirow{2}{*}{ Rataan } \\
\cline { 2 - 4 } & $\mathrm{B} 1$ & $\mathrm{~B} 2$ & $\mathrm{~B} 3$ & $\mathrm{~B} 4$ & \\
\hline A1 & $1,6135^{\mathrm{ab}}$ & $1,4411^{\mathrm{b}}$ & $1,2983^{\mathrm{b}}$ & $1,4317^{\mathrm{b}}$ & 1,4462 \\
$\mathrm{~A} 2$ & $1,7790^{\mathrm{a}}$ & $1,7172^{\mathrm{a}}$ & $1,2702^{\mathrm{b}}$ & $1,4174^{\mathrm{b}}$ & 1,5459 \\
A3 & $1,4714^{\mathrm{b}}$ & $1,4230^{\mathrm{b}}$ & $1,3957^{\mathrm{b}}$ & $1,4439^{\mathrm{b}}$ & 1,4335 \\
\hline Rataan & 1,6213 & 1,5271 & 1,3214 & 1,4310 & \\
\hline
\end{tabular}

$\mathrm{a}, \mathrm{b}$ : Superskrip dengan huruf kecil yang berbeda pada tabel menunjukkan berbeda nyata $(\mathrm{P}<0,05)$ 
Pada perlakuan B3 (Sludge padat dengan penambahan bahan organik abu sekam) menunjukkan berbeda tidak nyata $(\mathrm{P}>0,05)$, ini disebabkan oleh abu sekam merupakan bahan organik yang digunakan untuk meningkatkan kandungan kalium pupuk organik, meskipun abu sekam memiliki kandungan nitrogen tetapi sangat rendah dan tidak memberikan pengaruh yang nyata terhadap kandungan $\mathrm{N}$-organik pupuk organik yang dihasilkan. Rendahnya kandungan N-organik pada penambahan bahan peningkat campuran (B4) pada penelitian ini disebabkan oleh terangkatnya zat nitrogen dalam bentuk gas nitrogen atau dalam bentuk gas amoniak, yang terbentuk selama proses pengomposan dan pengemasan menjelang dilakukan penganalisaan kandungan unsur hara di laboratorium. Hal ini sesuai dengan pendapat Sutanto (2002) yang menyatakan bahwa penambahan nitrogen yang berlebihan dalam usaha meningkatkan mutu pupuk organik padat, dapat meningkatkan kehilangan nitrogen melalui proses penguapan dalam bentuk gas amoniak $\left(\mathrm{NH}_{3}\right)$ karena proses pengomposan.

Kandungan N-Organik tertinggi yang dihasilkan pada penelitian terdapat pada perlakuan A2B1 sebesar 1,7790\%, dalam penelitian ini belum memenuhi standar kualitas pupuk dari pasar khusus yaitu sebesar 2,30\%. Hal ini dikarenakan bahan baku yang digunakan dalam penelitian ini hanya memakai feses sapi, Sesuai dengan pendapat Simamora dan Salundik (2006) yang menyatakan bahwa besarnya persentase kandungan hara yang terdapat di dalam pupuk organik sangat bervariasi tergantung pada bahan baku yang digunakan.

\section{Kandungan Fosfor $\left(\mathrm{PO}_{4}\right)$}

Kandungan fospor pupuk organik padat yang didapat dari hasil penelitian ini yang tertinggi terdapat pada A1B2 yaitu sebesar 2,9089\%. dan yang terendah terdapat pada A2B3 yaitu sebesar $0,8004 \%$, seperti yang terlihat pada Tabel 2 .

Hasil analisis keragaman (Tabel 2) menunjukan bahwa kandungan fospor $\left(\mathrm{PO}_{4}\right)$ pupuk organik interaksi antara faktor $\mathrm{A}$ (Sludge biogas feses sapi perah dengan konsentrasi air yang berbeda) dengan faktor B (bahan organik peningkat) menunjukan berbeda nyata $(\mathrm{P}<0,05)$. Hasil uji lanjut Duncan's menunjukan bahwa kandungan fospor Sludge biogas dengan bahan peningkat, A1B1 berbeda nyata $(\mathrm{P}<0,05)$ dengan A1B2 dan berbeda tidak nyata $(\mathrm{P}>0,05)$ dengan perlakuan A1B3 dan A1B4. A2B1 berbeda nyata $(\mathrm{P}<0,05)$ dengan A2B2 dan berbeda tidak nyata $(P>0,05)$ dengan perlakuan A2B3 serta A2B4. A3B1 berbeda nyata $(\mathrm{P}<0,05)$ dengan $\mathrm{A} 3 \mathrm{~B} 2$ dan A3B4. Sedangkan perlakuan A3B1 berbeda tidak nyata $(\mathrm{P}>0,05)$ dengan perlakuan A3B3.

Berbeda nyatanya pengaruh dari perlakuan A1B2 dengan A2B2 disebabkan oleh perbandingan air yang digunakan dalam pengenceran bahan baku juga sangat mempengaruhi proses fermentasi bahan baku. Simamora dkk., (2006) menyatakan perbandingan kotoran sapi dengan air adalah

Tabel 2. Kandungan fosfor $\left(\mathrm{PO}_{4}\right)$ pupuk organik padat dari Sludge padat biogas feses sapi perah (\%)

\begin{tabular}{cccccc}
\hline Faktor A & \multicolumn{4}{c}{ Faktor B } & Rataan \\
\cline { 2 - 4 } & B1 & B2 & B3 & B4 & \\
\hline A1 & $1,1745^{\mathrm{bc}}$ & $2,9089^{\mathrm{a}}$ & $0,8604^{\mathrm{c}}$ & $1,5644^{\mathrm{b}}$ & 1,6270 \\
A2 & $1,0790^{\mathrm{c}}$ & $1,9272^{\mathrm{b}}$ & $0,8004^{\mathrm{c}}$ & $1,7329^{\mathrm{bc}}$ & 1,3849 \\
A3 & $0,9270^{\mathrm{c}}$ & $1,6556^{\mathrm{b}}$ & $1,0786^{\mathrm{c}}$ & $1,9252^{\mathrm{b}}$ & 1,3966 \\
\hline Rataan & 1,0602 & 2,1639 & 0,9131 & 1,7408 & 4,4085 \\
\hline
\end{tabular}

a, b, c : Superskrip dengan huruf kecil yang berbeda pada tabel menunjukkan berbeda nyata $(\mathrm{P}<0,05)$ 
1:2, sedangkan menurut Suriawiria (2006), perbandingan kotoran sapi dengan air adalah $1: 1$.

Selain itu, penambahan bahan organik juga mempengaruhi kandungan $\mathrm{PO}_{4}$ pada penelitian juga disebabkan oleh penambahan bahan organik terutama penambahan tepung tulang dapat meningkatkan kandungan fosfor karena tepung tulang merupakan sumber fosfor. Sesuai dengan pendapat Simamora dan Salundik (2006) menyatakan bahwa besarnya persentase unsur hara yang terdapat di dalam pupuk organik sangat bervariasi tergantung pada bahan tambahan yang ditambahkan ke dalam pupuk organik. Tepung tulang merupakan sumber kalsium (Ca) dan fosfor (P), jika dicampurkan dengan pupuk organik dapat meningkatkan unsur $\mathrm{P}$ yang terdapat di dalam pupuk organik tersebut.

Pada perlakuan B3 dan B4 dari Tabel 4 menunjukan pengaruh berbeda tidak nyata $(\mathrm{P}>0,05)$, ini dikarenakan abu sekam merupakan bahan organik yang digunakan untuk meningkatkan kandungan kalium pupuk organik, meskipun abu sekam memiliki kandungan nitrogen tetapi sangat rendah dan tidak memberikan pengaruh yang nyata terhadap kandungan $\mathrm{PO}_{4}$ pupuk organik yang dihasilkan. Kandungan fosfor yang dihasilkan pada penelitian ini telah memenuhi standar kualitas fosfor yang ditetapkan oleh pasar khusus yaitu minimal $\geq 1,60 \%$, kandungan $\mathrm{PO}_{4}$ tertinggi yang dihasilkan dalam penelitian ini terdapat pada kombinasi A1B2 sebesar 2,9089\%.

\section{Kandungan Kalium $\left(\mathrm{K}_{2} \mathrm{O}\right)$}

Kandungan rata-rata kalium pupuk organik yang tertinggi dalam penelitian ini terdapat pada taraf faktor A (Sludge biogas dari feses sapi perah dengan perbandingan air yang berbeda) yaitu A1 0,3136\%, A2 $0,1842 \%$, A3 0,2269\%. Sedangkan faktor B adalah, B1 0,1232\%, B2 0,2560\%, B3 $0,2553 \%$ dan B4 0,3319\%. Pada kombinasi faktor A dan faktor $B$, kandungan $\mathrm{K}_{2} \mathrm{O}$ tertinggi dihasilkan pada perlakuan A1B4 yaitu sebesar $0,4382 \%$, untuk lebih jelasnya dapat dilihat pada Tabel 3. Hasil analisis keragaman menunjukan bahwa interaksi antara faktor A dan Faktor B (Sludge padat biogas feses sapi perah dengan perbandingan air yang berbeda dengan penambahan bahan organik peningkat) menunjukan pengaruh yang berbeda tidak nyata $(\mathrm{P}>0,05)$. kandungan kalium pupuk organik padat pada faktor A (Sludge padat biogas feses sapi perah dengan perbandingan air yang berbeda) memperlihatkan pengaruh yang berbeda nyata $(\mathrm{P}<0,05)$ dan faktor $\mathrm{B}$ (bahan organik peningkat) menunjukan pengaruh yang berbeda nyata $(\mathrm{P}<0,05)$ terhadap kandungan kalium pupuk organik padat yang dihasilkan.

Hasil analisis laboratorium (Tabel 3) memperlihatkan kandungan kalium tertinggi terdapat pada A1 pada faktor A yaitu sebesar $0,3136 \%$ dan pada faktor B terdapat pada B4 yaitu sebesar $0,3319 \%$.

Tabel 3. Kandungan kalium $\left(\mathrm{K}_{2} \mathrm{O}\right)$ pupuk organik padat dari Sludge padat biogas feses sapi perah $(\%)$

\begin{tabular}{cccccc}
\hline \multirow{2}{*}{ Faktor A } & \multicolumn{4}{c}{ Faktor B } & Rataan \\
\cline { 2 - 4 } & B1 & B2 & B3 & B4 & \\
\hline A1 & 0,1422 & 0,4461 & 0,2280 & 0,4382 & $0,3136^{\mathrm{a}}$ \\
A2 & 0,1095 & 0,1530 & 0,1963 & 0,2782 & $0,1842^{\mathrm{b}}$ \\
A3 & 0,1180 & 0,1689 & 0,3416 & 0,2792 & $0,2269^{\mathrm{b}}$ \\
\hline Rataan & $0.1232^{\mathrm{b}}$ & $0,2560^{\mathrm{a}}$ & $0,2553^{\mathrm{a}}$ & $0,3319^{\mathrm{a}}$ & \\
\hline
\end{tabular}

$\mathrm{a}, \mathrm{b}$ : Superskrip dengan huruf kecil yang berbeda pada tabel menunjukkan berbeda nyata $(\mathrm{P}<0,05)$ 
Sedangkan pada kombinasi faktor A dan Faktor B, kandungan kalium tertinggi terdapat pada A1B4 (Sludge biogas dengan perbandingan air 1:1 dengan penambahan bahan organik peningkat campuran) yaitu sebesar $0,4382 \%$. Sedangkan kandungan kalium yang terendah terdapat pada A2B1 (Sludge biogas dengan perbandingan air 1:2 dengan penambahan tepung darah) yaitu sebesar $0,1095 \%$.

Pada Tabel 3 terlihat bahwa A1 berbeda nyata $(\mathrm{P}>0,05)$ dengan $\mathrm{A} 2$ serta $\mathrm{A} 3$, sedangkan antara A2 dengan A3 menunjukan pengaruh yang berbeda tidak nyata $(P>0,05)$. Perbedaan pada faktor $A$ disebabkan oleh salah satunya adalah perbandingan air yang digunakan dalam pengenceran bahan baku juga sangat mempengaruhi proses fermentasi bahan baku. perbandingan kotoran sapi dengan air adalah 1:2 Simamora dkk., (2006), sedangkan menurut Suriawiria (2006), perbandingan kotoran sapi dengan air adalah 1:1. Suriawiria (2009) menjelaskan bahwa air sangat penting dalam proses biologi bahan baku selama di dalam digester.

Faktor pada Tabel 3 menunjukan adanya pengaruh yang berbeda nyata $(\mathrm{P}>0,05)$, dimana perlakuan $\mathrm{B} 4$ menunjukan pengaruh yang berbeda nyata $\mathrm{P}<0,05)$ dengan B1. Dan B4 menunjukan pengaruh yang berbeda tidak nyata $(\mathrm{P}>0,05) \mathrm{B} 3$ dan $\mathrm{B} 2$, terjadinya penurunan antara B4 dengan B1. Simamora dan Salundik (2006) menyatakan, pada proses fermentasi dalam digester terjadi perombakan anaerobik bahan organik menjadi biogas dan asam yang mempunyai berat molekul rendah yang menyebabkan konsentrasi $\mathrm{N}, \mathrm{P}$ dan $\mathrm{K}$ meningkat

Penurunan kandungan kalium dari B4 ke B1 terjadi karena adanya penambahan bahan organik peningkat terutama abu sekam yang ditambahkan ke dalam pupuk organik. Terjadinya penurunan kandungan $\mathrm{K}$ pupuk organik padat yang dihasilkan dikarenakan penambahan bahan campuran pada pupuk organik padat saling melengkapi dalam peningkatan kandungan unsur hara $\mathrm{K}$.
Simamora dkk., (2006) menyatakan, besarnya persentase kandungan hara yang terdapat di dalam pupuk organik sangat bervariasi tergantung kepada salah satunya bahan baku yang digunakan dalam pembuatan pupuk organik itu sendiri dan bahan organik peningkat yang digunakan dalam meningkatkan kandungan tertentu.

Meskipun kandungan hara $\mathrm{K}_{2} \mathrm{O}$ yang dihasilkan mengalami peningkatan jika dibandingkan dengan kandungan $\mathrm{K}_{2} \mathrm{O}$ sebelum dilakukan penambahan bahan organik peningkat, kandungan kalium yang dihasilkan belum bisa memenuhi standar kualitas pupuk organik yang telah ditetapkan oleh pasar khusus sebesar $\geq 2,40 \%$. dan jika dibandingkan dengan kandungan kalium yang dihasilkan dari penelitian terdahulu, kandungan kalium pada penelitian ini masih rendah, kandungan $\mathrm{K}_{2} \mathrm{O}$ tertinggi yang dihasilkan pada penelitian ini terdapat pada kombinasi A1B4 sebesar 0,4382\% dan lebih rendah jika dibandingkan dengan penelitian yang dilakukan sebelumnya.Terjadinya perbedaan hasil yang didapat dalam penelitian ini disebabkan oleh bahan baku yang digunakan dalam pembuatan pupuk organik.

\section{KESIMPULAN}

Pengomposan Sludge biogas dengan penambahan bahan organik peningkat tepung tulang, tepung darah dan abu sekam serta campuran (tepung darah, tepung tulang dan abu sekam) dapat meningkatkan kandungan $\mathrm{N}, \mathrm{P}$ dan $\mathrm{K}$ pupuk organik padat, jika dibandingkan dengan Sludge biogas tanpa penambahan bahan organik peningkat. Kandungan N, P dan K tertinggi pupuk organik pada penelitian ini terdapat pada A2B1 (Sludge biogas dengan perbandingan air $1: 2$ dan penambahan tepung darah $1 \%$ ) untuk kandungan $\mathrm{N}$ yaitu sebesar $1,7790 \%$; 2,9089\% kandungan $\mathrm{PO}_{4}$ dengan penambahan tepung tulang 3\% pada A1B2 serta $0,4382 \%$ kandungan $\mathrm{K}_{2} \mathrm{O}$ dengan penambahan bahan organik campuran (tepung darah $1 \%$, tepung tulang $3 \%$ dan abu sekam $3 \%)$. 
Untuk meningkatkan kandungan $\mathrm{N}, \mathrm{P}$ dan $\mathrm{K}$ pupuk organik padat dari Sludge biogas feses sapi perah dengan perbandingan air yang berbeda dapat dilakukan dengan penambahan bahan peningkat tepung darah $1 \%$, tepung tulang $3 \%$ dan campuran (tepung darah $1 \%$, tepung tulang $3 \%$ dan abu sekam 3\%).

\section{DAFTAR PUSTAKA}

Simamora, S., Salundik., Wahyuni, S. 2006. Membuat Biogas Pengganti Bahan Bakar Minyak dan Gas dari Kotoran Ternak. Agromedia Pustaka. Cetakan 1, Jakarta.

\section{Modul Pelatihan, Pengolahan Limbah Peternakan Ramah}

Lingkungan dengan Teknologi Tepat Guna untuk Pengembangan Agribisnis (Produksi Gas Bio, Pupuk Organik Padat/cair). Institut Pertanian Bogor, Bogor.

dan Salundik. 2006. Meningkatkan Kualitas Kompos. Agromedia Pustaka. Cetakan 1, Jakarta.

Steel, R. G. D. dan J. H. Torrie. 1991. Prinsip dan Prosedur Statistik: Suatu Pendekatan Biometrik. Edisi Kedua. PT. Gramedia Pustaka Utama, Jakarta.

Sutanto, R. 2002. Penerapan Pertanian Organik Pemasyarakatan dan Pengembangannya. Cetakan. 5. Kanisius, Yogyakarta. 